\title{
Intestinal inflammation in cystic fibrosis
}

\author{
Rosalind L Smyth^, Nicholas M Croft`, Una O’Hea, Tom G Marshall, Anne Ferguson
}

${ }^{\star}$ Dr Smyth and Dr Croft contributed equally to this work.

University Institute of Child Health, Royal Liverpool Children's Hospital, Liverpool L12 2AP, UK

R L Smyth

U O'Hea

Department of Paediatric

Gastroenterology, St

Bartholomew's and the

Royal London School

of Medicine and

Dentistry, Queen Mary

and Westfield College,

London, UK

N M Croft

Gastrointestinal Unit, Department of Medicine, Western

General Hospital,

University of

Edinburgh, UK

A Ferguson

Royal Hospital for Sick Children, Edinburgh, UK

T G Marshall

Correspondence to:

Professor Smyth

email: r.1.smyth@liv.ac.uk

Accepted 31 January 2000

\begin{abstract}
Background-There is controversy about whether the inflammatory response observed in the cystic fibrosis (CF) lung occurs secondary to bacterial infection or is caused by a dysregulation of the inflammatory response associated with the basic cellular defect of $\mathrm{CF}$.
\end{abstract}

Aims-To study the inflammatory response in the gastrointestinal tract of children with CF; and to investigate whether there is increased inflammation in the gastrointestinal tract of CF children with fibrosing colonopathy.

Methods-Whole gut lavage was performed on 21 pancreatic insufficient children with CF, who were clinically well, five children with CF and fibrosing colonopathy, and 12 controls. Intestinal outputs of plasma derived proteins (albumin, $\alpha_{1}$ antitrypsin, IgG), secretory immunoglobulins (IgA and IgM), cellular constituents (eosinophil cationic protein and neutrophil elastase), and cytokines (interleukin 8 and interleukin $1 \beta$ ) were measured.

Results-Compared to controls, the $21 \mathrm{CF}$ patients, with no intestinal complications, had increased intestinal outputs of albumin, IgG, IgM, eosinophil cationic protein, neutrophil elastase, interleukin $1 \beta$, and interleukin 8. Similar values were obtained for the CF patients with fibrosing colonopathy.

Conclusions-These data suggest that there is immune activation in the gastrointestinal mucosa of children with cystic fibrosis, which may result from the basic cellular defect. Fibrosing colonopathy does not appear to be associated with increased inflammation.

(Arch Dis Child 2000;82:394-399)

Keywords: mucosal immunity; cytokines; intestinal inflammation; whole gut lavage

The major cause of morbidity and death in cystic fibrosis (CF) patients relates to chronic bronchopulmonary infection which results in progressive bronchiectasis and eventually respiratory failure. An intense, neutrophil dominated inflammation of the airways ${ }^{1}$ is associated with the chronic infection and has generally been assumed to result from it. High concentrations of inflammatory markers have been reported in the blood of CF patients compared with controls and these correlated with measurements of disease severity. ${ }^{2-5}$ In the CF lung increased amounts of neutrophils, elastase, and cytokines have been reported in the bronchoalveolar lavage (BAL) fluid. ${ }^{367}$ These findings have been described, not only in
CF patients with established lung disease and bronchiectasis, but in very young infants with minimal or no detectable lung disease..$^{8-10}$ One group suggested that bacterial infection may initiate inflammation. ${ }^{8}$ Others suggested that inflammation is the initial event in the CF lung, causing damage and increasing susceptibility to infections. ${ }^{910}$ Thus there is currently controversy about whether the basic cellular defect in $\mathrm{CF}$ is associated with an inflammatory response per se, or whether the inflammatory response in the CF lung occurs secondary to bacterial infection.

We have investigated this question by studying the inflammatory response in CF in an organ other than the lung, the gastrointestinal tract. Whole gut lavage (WGL), which has been used in CF as a treatment of distal intestinal obstruction syndrome, results in a clear fluid (WGLF), essentially a gut perfusate. ${ }^{11}$ By administering the fluid to individuals at an equal rate, one can directly compare the concentrations of immune and inflammatory parameters in the resulting effluent. This has been used widely in clinical research in inflammatory bowel disease in both adults and children. ${ }^{12-14}$ As WGL is a gut perfusate with a steady state of output of proteins into the fluid, ${ }^{11}{ }^{15}$ this allows estimation of the output of intestinal proteins from the mucosa of the whole gut.

We have previously undertaken a small study in CF children using WGL to investigate whether high strength pancreatic enzymes were associated with gut inflammation. ${ }^{16}{ }^{17}$ We found evidence of gross inflammation in two children with distal intestinal obstruction syndrome. ${ }^{16}$ There were also small, but significant increases in the WGLF concentrations of albumin, interleukin 1 (IL-1), and IL-8 in children with CF. These raised parameters did not alter when five of the children were changed to low dose pancreatic supplements. ${ }^{17}$

In this study we have extended this work to include more subjects and to look for evidence of inflammation in five children with fibrosing colonopathy. ${ }^{18}$ Instead of comparing the concentrations of proteins in the resulting lavage fluid, we have calculated the total intestinal outputs of proteins. This eliminates any possible errors that may be a consequence of individual children tolerating the administration of WGLF at different rates, which can affect the WGLF concentrations. Thus we are able to present the first directly measured intestinal outputs of proteins from gastrointestinal tracts of children and compare the results with published adult data. As secretory immunoglobulins (IgA and $\operatorname{IgM}$ ) and eosinophil cationic protein $(\mathrm{ECP})^{19}$ are thought to play major roles in the pathophysiology of $\mathrm{CF}$, 
Table 1 Daily intestinal output of proteins in whole gut lavage fluid from children with CF and controls

\begin{tabular}{|c|c|c|c|c|}
\hline \multirow[b]{2}{*}{ Group } & \multirow[b]{2}{*}{ Substance } & \multicolumn{2}{|l|}{ Median output } & \multirow[b]{2}{*}{$p$ value } \\
\hline & & $\begin{array}{l}\text { Controls } \\
(n=12)\end{array}$ & $\begin{array}{l}\text { CF patients } \\
(n=21)\end{array}$ & \\
\hline \multirow{3}{*}{$\begin{array}{l}\text { Predominantly plasma } \\
\text { derived proteins }\end{array}$} & Albumin (mg/kg/day) & 2.5 & 8.3 & 0.0004 \\
\hline & $\alpha_{1}$ Antitrypsin (mg/kg/day) & 2.2 & 3.6 & 0.1 \\
\hline & $\operatorname{IgG}(\mathrm{mg} / \mathrm{kg} /$ day $)$ & 0.6 & 1.5 & 0.01 \\
\hline \multirow[t]{2}{*}{ Secretory immunoglobulins } & $\operatorname{IgA}(\mathrm{mg} / \mathrm{kg} /$ day $)$ & $35.4(\mathrm{n}=9) \dagger$ & $50.0(\mathrm{n}=17) \ddagger$ & 0.2 \\
\hline & $\operatorname{IgM}(\mathrm{mg} / \mathrm{kg} /$ day $)$ & 1.0 & $2.7(\mathrm{n}=17) \ddagger$ & 0.03 \\
\hline \multirow[t]{2}{*}{ Cytokines } & IL-1 $\beta(\mu \mathrm{g} / \mathrm{kg} /$ day $)$ & $3.6(\mathrm{n}=9) \ddagger$ & 13.3 & 0.02 \\
\hline & IL-8 $(\mu \mathrm{g} / \mathrm{kg} /$ day $)$ & 0.0 & 64 & $<0.00$ \\
\hline \multirow[t]{2}{*}{ Cell products } & $\begin{array}{l}\text { Eosinophil cationic } \\
\text { protein }(\mu \mathrm{g} / \mathrm{kg} / \text { day })\end{array}$ & $8.9(\mathrm{n}=10) \ddagger$ & $18.7(\mathrm{n}=17) \ddagger$ & 0.01 \\
\hline & $\begin{array}{l}\text { Neutrophil elastase } \\
\text { (mkat/kg/day) }\end{array}$ & $0(\mathrm{n}=10) \ddagger$ & 6.6 & 0.04 \\
\hline
\end{tabular}

${ }^{\star}$ Mann-Whitney U test.

†Three specimens excluded for technical reasons.

$\ddagger$ Where there were insufficient specimens the exact number analysed is shown in brackets.

for this study, we added these to the panel of immune and inflammatory markers.

\section{Methods}

SUBJECTS

Whole gut lavage was performed electively on 26 pancreatic insufficient CF patients. Five of these were diagnosed as having fibrosing colonopathy. Three children had required surgical resection for fibrosing colonopathy at least one year prior to the WGL. One was diagnosed with fibrosing colonopathy some weeks after the WGL and subsequently required a right hemicolectomy. The fifth had radiological appearances of fibrosing colonopathy, but did not require surgery. All five patients with a diagnosis of fibrosing colonopathy were receiving low dose pancreatic enzyme preparations at the time of the WGL. The remaining 21 children (median age 8.5 years, range 1.6-14.5) were receiving pancreatic enzyme supplements (12 receiving high dose preparations and nine low dose preparations). None of these 21 children had distal intestinal obstruction syndrome or any other abdominal pathology at the time of WGL. Twelve children were studied as immunologically normal controls (aged 11 months to 13 years). Eight had lavage for an essentially normal colonoscopy (one had a rectal polyp); in four it was performed to treat severe constipation.

The studies were performed in Edinburgh (13 patients and 12 controls), Liverpool (12 patients), and Leicester (one patient). The studies were approved by the Paediatrics/ Reproductive Medicine Subcommittee of the Lothian Research Ethics Committee, the Liverpool Paediatric Research Ethics Committee, and the Leicestershire Ethics Committee.

Physiotherapy was performed before the WGL and any sputum was expectorated during the lavage. Following an overnight fast, a polyethylene glycol based electrolyte solution (Klean-Prep, Norgine, UK) was taken orally or administered by nasogastric tube or gastrostomy tube at a rate of approximately 15 $\mathrm{ml} / \mathrm{kg} / \mathrm{h}$. The exact rate was recorded for each child as some children tolerated faster or slower rates better. The resulting effluent was collected once clear of all faecal material. Aliquots
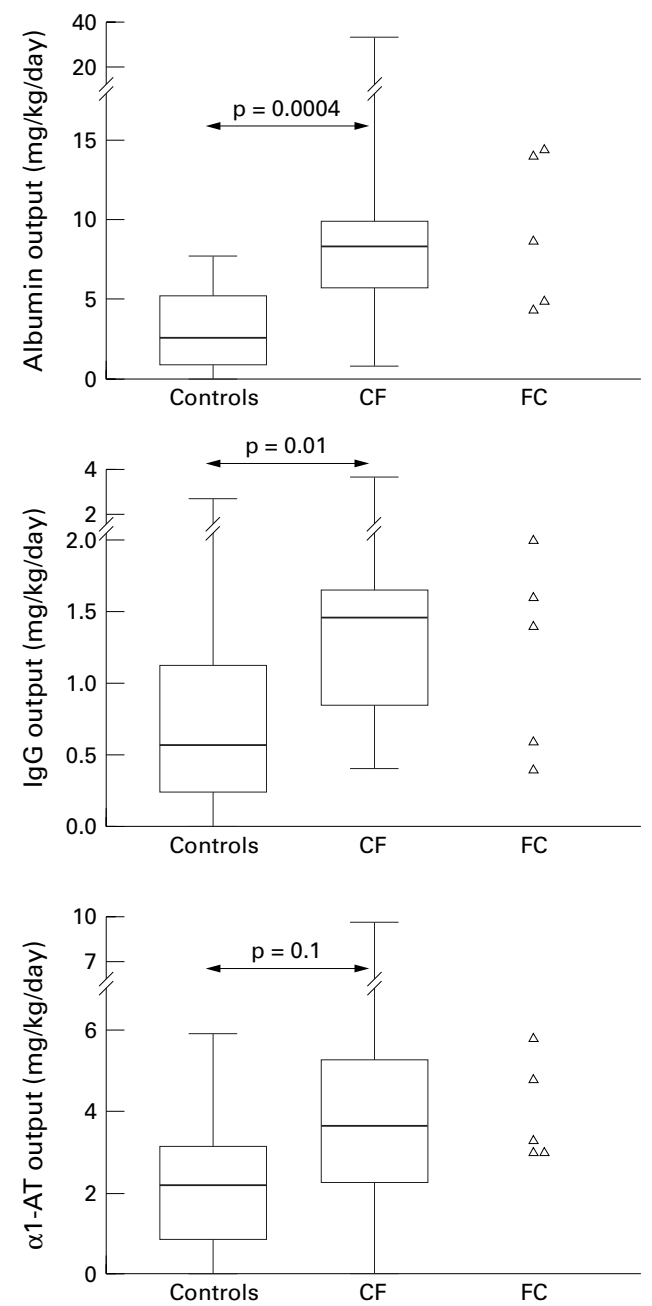

Figure 1 Intestinal output of plasma derived proteins in whole gut lavage fluid from children with $C F$ and controls. Children with fibrosing colonopathy $(F C)$ are shown by individual points. The box indicates the median and interquartile range, the whiskers are the whole range; $p$ values are derived from the Mann-Whitney $U$ test for non-parametric data. There were insufficient specimens for all the assays to be performed in all the children.

of this were collected, immediately processed with antibacterial and protease inhibitors, and stored in aliquots at $-70^{\circ} \mathrm{C} .^{20}$

\section{MEASUREMENTS}

Albumin and $\alpha_{1}$ antitrypsin $\left(\alpha_{1}-\mathrm{AT}\right)$ were assayed by immunoturbidimetric procedures. ${ }^{21}$ Enzyme linked immunosorbent assays (ELISAs), which had been developed in our laboratory ${ }^{20}$ were performed to assay $\operatorname{IgA}, \operatorname{IgG}$, and IgM. Commercially available kits were adapted to perform ELISAs for IL-8 (R\&D Systems Inc., Minneapolis, USA) and IL-1 $\beta$ (Cistron, Biotechnology, New Jersey, USA). ECP was measured by radioimmunoassay (Kabi-Pharmacia, Uppsala, Sweden). Total neutrophil elastase was measured by an enzymatic technique as described previously. ${ }^{22}$ In order to calculate the output of the protein (per kg per day), the concentration (per ml) of lavage fluid was multiplied by the rate of lavage ( $\mathrm{ml}$ per day) and divided by the weight of the child (kg). 

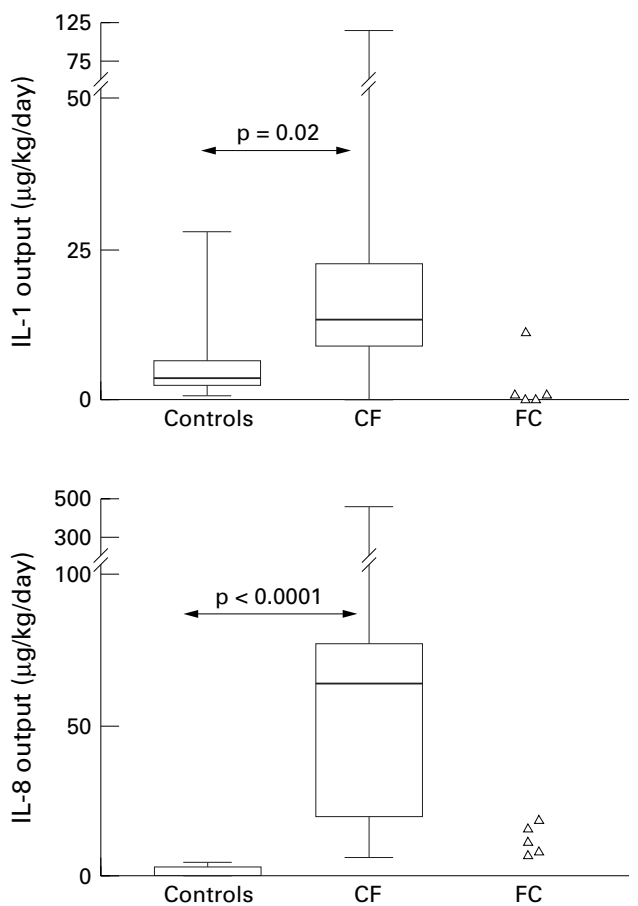

Figure 2 Intestinal output of cytokines in whole gut lavage fluid from children with $C F$ and controls. Children with fibrosing colonopathy (FC) are shown by individual points. The box indicates the median and interquartile range, the whiskers are the whole range; $p$ values are derived from the Mann-Whitney $U$ test for non-parametric data. There were insufficient specimens for all the assays to be performed in all the children.

DATA ANALYSIS

The data for the 21 pancreatic insufficient $\mathrm{CF}$ patients were aggregated and displayed as box (indicating interquartile ranges with medians in the boxes) and whisker (indicating ranges) plots. Data for the 12 control patients were displayed in a similar manner. Data for the three patients who had had surgery for fibrosing colonopathy and the two with fibrosing colonopathy who had not received surgery were shown separately as individual data points. Comparisons between the two groups of subjects (21 CF patients and 12 controls) were performed by the Mann-Whitney test. Probability values less than 0.05 were considered significant.

\section{Results}

Lavage procedures were successfully completed in $26 \mathrm{CF}$ patients. A further four children were recruited to the study, but the WGL procedure was discontinued before the study was completed because the children complained of abdominal pain and distension and were finding it difficult to tolerate the ingestion of large volumes of the electrolyte solution. Table 1 and figs $1,2,3$, and 4 summarise the results.

Compared with the control group, the CF patients had significantly increased concentrations of albumin, IgG, IgM, IL- $1 \beta$, IL-8, neutrophil elastase, and ECP. There were no significant differences between the CF patients and controls for $\alpha_{1}-\mathrm{AT}$ and IgA. There was no significant difference between the median weight for age $\mathrm{z}$ scores of the $21 \mathrm{CF}$ patients
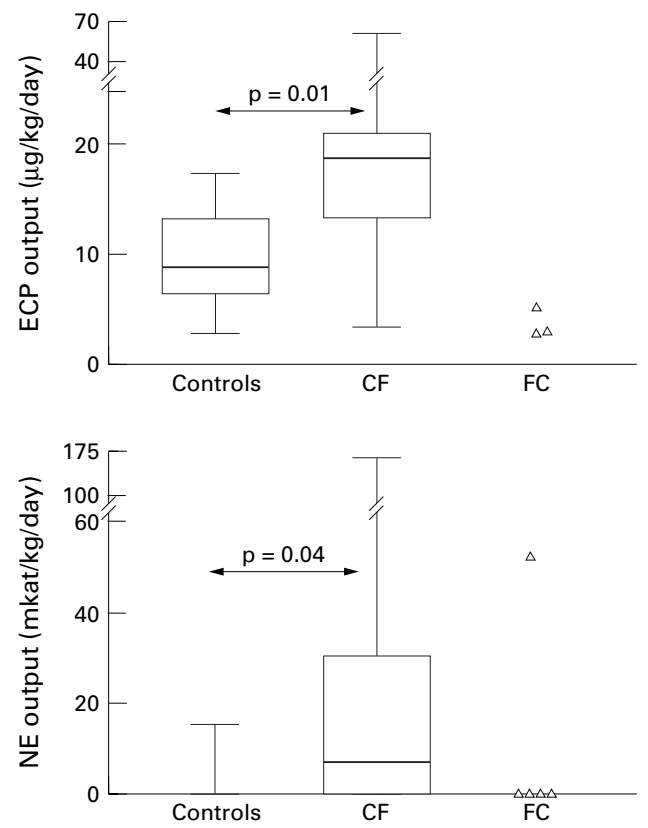

Figure 3 Intestinal output of cellular constituents in whole gut lavage fluid from children with $C F$ and controls. Children with fibrosing colonopathy (FC) are shown by individual points. The box indicates the median and interquartile range, the whiskers are the whole range; $p$ values are derived from the Mann-Whitney $U$ test for non-parametric data. There were insufficient specimens for all the assays to be performed in all the children. NE, neutrophil elastase.
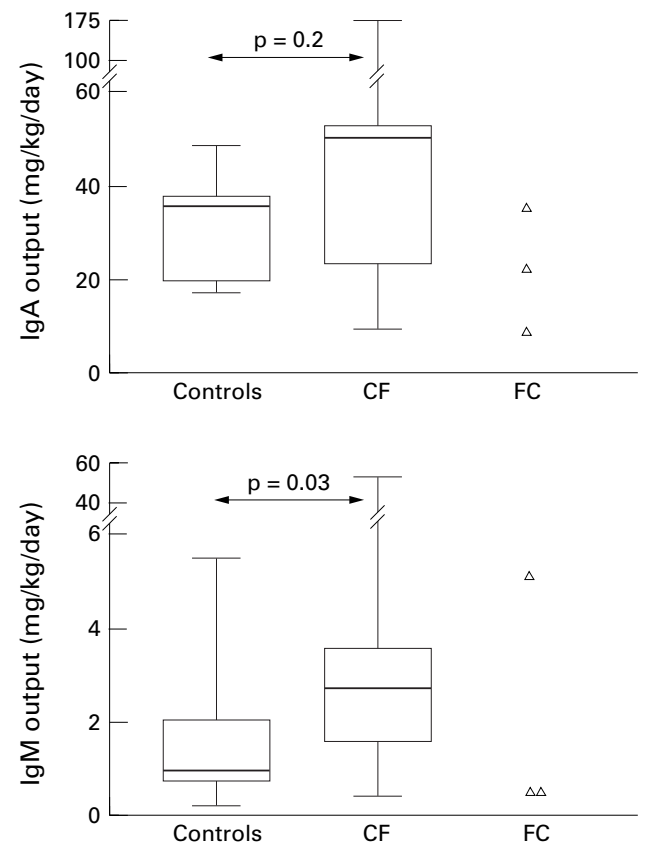

Figure 4 Intestinal output of secretory immunoglobulins in whole gut lavage fluid from children with $C F$ and controls. Children with fibrosing colonopathy (FC) are shown by individual points. The box indicates the median and interquartile range, the whiskers are the whole range; $p$ values are derived from the Mann-Whitney $U$ test for non-parametric data. There were insufficient specimens for all the assays to be performed in all the children.

without fibrosing colonopathy and the controls. Because of the small numbers, we did not compare the patients with fibrosing colonopathy with either of the other two groups, but as shown in the figures, values obtained for 
patients with fibrosing colonopathy generally fell within the normal CF patients' ranges. When we compared the 12 patients receiving high strength pancreatic enzyme preparations with the nine receiving low strength preparations, we found no significant differences in any of substances measured apart from IgM, which was higher in children taking high strength preparations (data not shown, $\mathrm{p}=0.005$ ).

\section{Discussion}

We have shown increased intestinal outputs of plasma derived proteins (albumin and IgG), a secretory immunoglobulin (IgM), cellular constituents (ECP), and cytokines (IL-8 and IL-1 $\beta$ ) in the WGLF of children with cystic fibrosis compared with disease free controls. We know that none of the children had significant gastrointestinal tract bleeding as the WGLF haemoglobin was not raised (data not shown). None of the inflammatory markers were increased in the five patients with a diagnosis of fibrosing colonopathy compared to $\mathrm{CF}$ patients without this condition. This indicates that, at the time these children were studied, there was no evidence of active inflammation in the gastrointestinal tract as a consequence of fibrosing colonopathy. However, three of these children had undergone surgical resection of the part of their colons likely to be most affected by fibrosing colonopathy. It is possible that fibrosing colonopathy may be the end result of a process of inflammation, which was no longer active at the time these children were studied. This study was not designed to address the question of whether CF patients receiving high dose pancreatic enzyme preparations had increased cytokines and other substances in WGL compared with CF patients receiving low strength preparations. Our previous study ${ }^{17}$ did not show any differences in concentrations of any substances measured in WGL in five children on high strength preparations who switched to low strength preparations and were studied again. We were only able to measure $\operatorname{IgM}$ in five of nine patients in the low strength group and it is possible that the increased IgM in WGL of children on high strength preparations was a spurious statistical finding.

Our data on intestinal output of proteins are the first published data in children. In adults, using a balloon perfusion system, total IgA secretion has been estimated to be approximately $40 \mathrm{mg} / \mathrm{kg} /$ day. $^{23}$ This is very similar to our figure in control children $(35.4 \mathrm{mg} / \mathrm{kg} /$ day) and that found in adult controls who have undergone WGL (32.5 mg/kg/day). ${ }^{16}$ WGL allows direct assessment of whole gut secretion, whereas in balloon perfusion systems it is necessary to make assumptions about the length of the bowel. By assessing output (rather than concentration) of proteins in a perfusion system, we have eliminated the need to measure dilution markers, which complicate the interpretation of similar techniques such as BAL. The use of such markers in BAL studies is controversial.

In studies which have used BAL to investigate airway inflammation in $\mathrm{CF}$, increased concentrations of immunoglobulins, ${ }^{7}$ neutrophil elastase, ${ }^{13} 7$ IL-8, ${ }^{6} 910$ and IL-1 $\beta^{6-10}$ have been found in the BAL of $\mathrm{CF}$ patients compared with controls. ECP has been found to be increased in the serum of CF patients compared with controls and the concentration of ECP was correlated with disease severity and poor pulmonary function. ${ }^{5}$ These studies have confirmed that inflammation in CF is not confined to the lungs, but is also present in the gastrointestinal tract.

Previous studies of mucosal inflammation in the gastrointestinal tract of CF patients have been very limited and we are the first group, to our knowledge, to investigate this using WGL. Using light microscopy, the presence of chronic inflammatory infiltration in the intestinal mucosa of some children with $\mathrm{CF}$ has been shown ${ }^{24}$; however others have not shown significant abnormalities. ${ }^{25}{ }^{26}$ Maiuri et al studied duodenal and bronchial mucosa of CF patients and identified abnormally high DNA fragmentation and likely apoptosis compared to controls. ${ }^{27}$ They speculated that this was related to the lack of CFTR in the epithelial cells. Falchuk and Taussig ${ }^{28}$ showed increases in the number of IgA secreting plasma cells and in vitro secretion of IgA from biopsy specimens of the jejunal mucosa in children with cystic fibrosis. This did not correlate with Schwachman score, severity of lung disease, bacteria in sputum cultures, or serum IgA concentrations. These in vitro data suggest that increased IgA secretion is a consequence of increased local production of the immunoglobulin rather than alteration of the intraluminal environment. We have not shown significantly increased $\operatorname{IgA}$ output in our CF patients, possibly because of the relatively small numbers.

The discordance between the findings in the WGL for albumin (which was raised in the CF patients) and $\alpha_{1}$-AT (which was not raised), are of interest, because stool $\alpha_{1}$-AT is regarded as the best diagnostic test for protein losing enteropathy. As albumin is rapidly broken down in faecal material, whereas $\alpha_{1}$-AT is not, measurement of stool $\alpha_{1}$-AT is preferable to stool albumin. However, it is feasible that measurement of albumin using WGL would be a more sensitive diagnostic test for protein losing enteropathy.

Briars et al measured IL- 8 and tumour necrosis factor $\alpha$ in the faeces of CF patients. ${ }^{29}$ They found a negative correlation between faecal IL-8 concentrations and measures of pulmonary function and speculated that the source of these high concentrations of cytokines was from swallowed sputum. Increased concentrations of cytokines such as IL-8 are found in the sputum of patients with $\mathrm{CF}^{30}$ but we feel that cytokines we observed in the WGLF of children with CF were not solely derived from sputum for the following reasons. We have previously undertaken a study in CF children where IL-8 was assayed in the sputum and the weights of sputum which would have to be swallowed per hour to account for the amounts detected in lavage fluid were calculated. ${ }^{16}$ Calculated values ranged from 0.9 to $61 \mathrm{~g}$ per hour and four children, all with 
detectable IL-8 in WGLF, could not participate because they were unable to expectorate sputum. As part of this study, parents were asked to perform usual chest physiotherapy on the morning before lavage and to expectorate sputum during the procedure. This was to ensure that the amount of sputum swallowed during the test was kept to a minimum. It is possible that bacteria, or other contents of swallowed sputum may be involved in direct stimulation of the intestinal mucosa, but this would be impossible to address in vivo as it would require excluding sputum from the gastrointestinal tract for prolonged periods (days or weeks).

In this study we have not investigated the intestinal flora of the subjects and thus cannot be certain that the flora in the small bowel was normal. However, none of the children had any symptoms suggestive of bacterial overgrowth. Small bowel flora has previously been studied in $\mathrm{CF}$ patients and no abnormalities were found. ${ }^{31}$

Armstrong et al performed BAL in a group of CF infants with a mean age of less than 3 months, and found that lower respiratory tract infection was present in almost $40 \% .{ }^{8}$ Total cell count and IL- 8 concentrations were increased in these infants compared with uninfected CF infants and controls. They concluded that the inflammation occurred secondary to infection.

This view was challenged by the findings of two groups of investigators who performed BAL on infants with CF and found evidence of lung inflammation in the BAL in the absence of microbiological evidence of bacterial infection. ${ }^{9}{ }^{10}$ These studies added weight to the hypothesis that the inflammatory component of CF lung disease may be initiated or at least amplified by the basic defect in $\mathrm{CF}^{32}$

This has been investigated further by both clinical and experimental studies in the lung and airway epithelia. Noah et al performed BAL studies in infants with and without CF. ${ }^{33}$ They measured cell counts and performed assays for a number of cytokines including IL-6, IL-8, and IL-10. They also cultured a variety of bacterial pathogens from both infants with CF and the non-CF controls. These included Moraxella catarrhalis, Staphylococcus aureus, and Haemophilus influenzae. They found that at a given bacterial load, CF infants had higher concentrations of neutrophils and IL-8 compared with non-CF controls. This relation was found also when a single pathogen, $H$ influenzae, was examined.

Normal airway epithelial cells release IL-8 in response to neutrophil elastase, which is present in high concentrations in the respiratory epithelial lining fluid of CF patients. ${ }^{34}$ However there are likely to be mechanisms other than the influx of neutrophils operating to stimulate cytokine productions. Studies using CF bronchial epithelial cells have shown that excessive amounts of IL- 6 and IL- 8 are generated when the cells are stimulated with the proinflammatory cytokines tumour necrosis factor $\alpha$ or IL- $1 \beta .^{35}$ This response was potentiated by prior exposure of the cells to prostaglandin $\mathrm{E}_{2} \cdot{ }^{36}$ Furthermore, in the murine
CF model, studies of airway mucociliary clearance and inflammation have suggested that abnormalities in these parameters occur before infection of the airways. ${ }^{37}$

As with the lung, cystic fibrosis transmembrane regulator (CFTR) gene expression is relatively high in the small and large intestine, ${ }^{38}$ and is increased in mucosal epithelial cells that are near lymph nodes. There are a number of potential mechanisms by which abnormal CFTR function may lead to dysregulation of the inflammatory responses. Arachidonic acid, a precursor of proinflammatory lipid mediators, is released in abnormally high concentrations from epithelial cells expressing the deltaF508 mutation in CFTR. ${ }^{39}$ IL-10 is a regulatory cytokine which is known to suppress inflammation in the lung and is present in reduced concentrations in BAL fluid from CF patients. ${ }^{40}$ If this dysregulation of inflammatory response was related to absent or abnormal CFTR, it is biologically plausible that it should be present not only in the lungs, but in other organs where CFTR is expressed.

Our results provide important insights into the possible association between the basic defect of CF and inflammation. By studying the inflammatory response in an organ other than the lung, we have shown evidence of inflammation at a site where pathogenic bacterial colonisation and infection does not normally occur. We suggest that in an environment in which CFTR does not function normally, the inflammatory response is deranged; this may be related to the pathological effects observed in CF.

We thank Dr O'Callaghan, University of Leicester, for allowing us to include one of his patients in this study. This study was supported by a grant from Solvay Healthcare (UK) Ltd. NC was supported by the Allan Fellowship, Faculty of Medicine, supported by the Allan
University of Edinburgh.

1 Birrer P, McElvaney NG, Rudeberg A, et al. Proteaseantiprotease imbalance in the lungs of children with cystic antiprotease imbalance in the lungs of children with cysti

2 Suter S, Schaad UB, Roux-Lombard P Girardin E, Grau G, Dayer J-M. Relation between tumour necrosis factor alpha and granulocyte elastase-alpha-1-protease inhibitor complexes in the plasma of patients with cystic fibrosis. Am Rev Respir Dis 1989;140:1640-4.

3 Meyer KC, Lewandoski JR, Zimmerman JJ, Nunley D, Calhoun WJ, Dopico GA. Human neutrophil elastase and elastase/alpha-1-antiprotease complexes in CF. Am Rev Respir Dis 1991;144:580-5.

4 Rayner RJ, Wiseman MS, Cordon SM, Norman D, Hiller EJ, Shale DJ. Inflammatory markers in cystic fibrosis. Respir Med 1991;85:139-45.

5 Koller DY, Gotz M, Wojnarowski C, Eichler I. Relationship between disease severity and inflammatory markers in cystic fibrosis. Arch Dis Child 1996;75:498-501.

6 Wilmott RW, Kassab JT, Kilian PL, Benjamin WR, Douglas $\mathrm{SD}$, Wood RE. Increased levels of interleukin-1 in bronchoalveolar washings from children with bacterial pulbronchoalveolar washings from children with bacterial pul-
monary infections. Am Rev Respir Dis 1976;142:365-8.

7 Konstan MW, Hilliard KA, Norvell TM, Berger M. Konstan MW, Hillard KA, Norvell TM, Berger $M$. with stable, clinically mild lung disease suggest ongoing infection and inflammation. Am $\mathcal{F}$ Respir Crit Care Med 1994;150:448-54.

8 Armstrong DS, Grimwood K, Carzino R, Carlin JB, Olinsky $A$, Phelan PD. Lower respiratory infection and inflammation in infants with newly diagnosed cystic fibrosis. BMF 1995;310:1571-2

9 Khan TZ, Wagener JS, Bost T, Martinez J, Accurso FJ, Riches DWH. Early pulmonary inflammation in infants with cystic fibrosis. Am 7 Respir Crit Care Med 1995;151: 1075-82.

10 Balough K, McCubbin M, Weinberger M, Smits W, Ahrens R, Fick R. The relationship between infection and inflammation in the early stages of lung disease from cystic fibromation in the early stages of lung dis
sis. Pediatr Pulmonol 1995;20:63-70.

11 O'Mahony S, Barton JR, Crichton S, Ferguson A. Appraisal of gut lavage in the study of intestinal humoral immunity. Gut 1990;31:1341-4. 
12 Choudari CP, O'Mahony S, Brydon G, Mwantembe O, Ferguson A. Gut lavage fluid protein concentrations: objective measures of disease activity in inflam

13 Troncone R, Caputo N, Campanozzi A, et al. Gut lavage $\mathrm{IgG}$ and interleukin-1 receptor antagonist:interleukin-1 beta ratio as markers of intestinal inflammation in children with inflammatory bowel disease. Gut 1997;41:60-5.

14 Troncone R, Caputo N, Esposito V, et al. Increased concentrations of eosinophilic cationic protein in whole-gut lavage fluid from children with inflammatory bowel disease. $f$ Pediatr Gastroenterol Nutr 1999;28:164-8.

15 Ferguson A, Sallam J, O'Mahony S, Poxton I. Clinical investigation of gut immune responses. Advanced Drug Delivery Reviews 1995;18:53-71.

16 Croft NM, Marshall TG, Ferguson A. Gut inflammation in children with cystic fibrosis on high-dose enzyme supplements. Lancet 1995;346:1265-7.

17 Croft NM, Marshall TG, Ferguson A. Direct assessment of gastrointestinal inflammation and mucosal immunity in gastrointestinal inflammation and mucosal immunity in

18 Smyth RL, Ashby D, O'Hea U, Burrows E, Lewis PA, van Velzen D, Dodge JA. Fibrosing colonopathy in cystic fibrosis: results of a case-control study. Lancet 1995:346:1247-51.

19 Koller DY, Gotz M, Eichler I, Urbanek R. Eosinophilic activation in cystic fibrosis. Thorax 1994;49:496-9.

20 O'Mahony S, Arranz E, Barton JR, Ferguson A. Dissociation between systemic and mucosal humoral immune response in coeliac disease. Gut 1991;32:29-35.

21 Choudari CP, O'Mahony S, Brydon G, Mwantembe O, Ferguson A. Concentrations of immunoglobulin G, albumin and alpha-1-antitrypsin in whole gut lavage fluid: objective measures of disease activity in inflammatory bowel disease. Gastroenterology 1993;104:1064-71.

22 Handy LM, Ghosh S, Ferguson A. Investigation of neutrophils in the gut lumen by assay of granulocyte elastase in whole gut lavage fluid. Scand $\mathcal{F}$ Gastroenterol 1996;31:700-5.

23 Conley ME, Delacroix DL. Intravascular and mucosal immunoglobulin A: two separate, but related systems of immunoglobulin A: two separate, but related sys

24 Antonowicz I, Lebenthal E, Swachman H. Disaccharidase activities in small intestinal mucosa in patients with cystic fibrosis. F Pediatr 1978;92:214-19.

25 Freye HB, Kurtz SM, Spock A, Capp MP. Light and electron microscopic examination of the small bowel of children with cystic fibrosis. F Pediatr 1964;64:575-9.

26 Morin, CL, Roy CC, Lasalle R, Bonin A. Small bowe mucosal dysfunction in patients with cystic fibrosis. F Pediatr 1976;88:213-16.

27 Maiuri L, Raia V, de Marco G, et al. DNA fragmentation is a feature of cystic fibrosis epithelial cells: a disease with inappropriate apoptosis? FEBS Lett 1997;408:225-31.
28 Falchuk, ZM, Taussig LM. IgA synthesis by jejunal biopsies from patients with cystic fibrosis and hereditary pancreatitis. Pediatrics 1973;51:49-54.

29 Briars GL, Dean TP, Murphy JL, Rolles CJ, Warner JO. Faecal interleukin 8 and tumour necrosis factor $\alpha$ concentration in cystic fibrosis. Arch Dis Child 1995;73:74-6.

30 Dean TP, Dai Y, Shute JK, Church MK, Warner JO. Interleukin-8 concentrations are elevated in bronchoalveolar lavage, sputum and sera of patients with cystic fibrosis. Pediatr Res 1993;34:159-61.

31 Anderson CM, Langford RF. Bacterial content of small intestine of children in health, in coeliac disease, and in fibro-cystic disease of pancreas. BMF 1958;i:803-6.

32 Cantin A. Cystic fibrosis lung inflammation: early, sustained and severe [editorial]. Am $\mathcal{F}$ Respir Crit Care Med 1995;151: 939-41.

33 Noah TL, Black HR, Cheng P-W, Wood RE, Leigh MW. Nasal and bronchoalveolar lavage fluid cytokines in early cystic fibrosis. F Infect Dis 1997;175:638-47.

34 Nakamura H, Yoshimura K, McElvaney NG, Crystal RG. Neutrophil elastase in respiratory epithelial lining fluid of individuals with cystic fibrosis induces interleukin- 8 gene expression in a human bronchial epithelial cell line. $\mathcal{f}$ Clin Invest 1992;89:1478-84.

35 Stecenko A, Breyer R, Canonico A, Dworski R, King G, Torii K, Brigham K. Exaggerated inflammatory response in CF airway epithelial cells. Pediatr Pulmonol 1997;14 (suppl):320.

36 Stecenko AA, King G, Torii K, Tanaguchi M, Brigham KL, Dworski R, Breyer R. PGE 2 markedly potentiates cytokine production by cystic fibrosis bronchial epithelial cells. $A m \mathcal{F}$ Respir Crit Care Med 1998,157:A259.

37 Zahm JM, Gaillard D, Dupuit F, Hinnrasky J, Porteous D, Dorin JR, Puchelle E. Early alterations in airway mucociliary clearance and inflammation of the lamna propria in CF mice. Am 7 Physiol 1997:272:C853-9.

38 Strong TV, Boehm K, Collins FS. Localization of cystic fibrosis transmembrane regulator mRNA in the human gastrointestinal tract by in situ hybridization. $\mathcal{F}$ Clin Invest 1994;93:347-54.

39 Miele L, Cordella Miele E, Xing M, Frizzell R, Mukherjee AB. Cystic fibrosis gene mutation (deltaF508) is associated with an intrinsic abnormality in $\mathrm{Ca} 2+$-induced arachidonic acid release by epithelial cells. DNA Cell Biol 1997;16:74959.

40 Bonfield TL, Panuska JR, Konstan MW, Hilliard KA, Hilliard JB, Ghnaim H, Berger M. Inflammatory cytokines in cystic fibrosis lungs. Am f Crit Care Med 1995;152:2111- 